University of South Florida

DIGITAL COMMONS

Digital Commons @ University of

@ UNIVERSITY OF SOUTH FLORIDA

South Florida

School of Geosciences Faculty and Staff

Publications

$4-1990$

\title{
Comment on "Timing of Mantle Upwelling: Evidence for a Passive Origin for the Red Sea Rift" by A. V. McGuire and R. G. Bohannon
}

Timothy H. Dixon

thd@usf.edu

Follow this and additional works at: https://digitalcommons.usf.edu/geo_facpub

Part of the Earth Sciences Commons

\section{Scholar Commons Citation}

Dixon, Timothy H., "Comment on "Timing of Mantle Upwelling: Evidence for a Passive Origin for the Red Sea Rift" by A. V. McGuire and R. G. Bohannon" (1990). School of Geosciences Faculty and Staff Publications. 509.

https://digitalcommons.usf.edu/geo_facpub/509

This Article is brought to you for free and open access by the School of Geosciences at Digital Commons @ University of South Florida. It has been accepted for inclusion in School of Geosciences Faculty and Staff Publications by an authorized administrator of Digital Commons @ University of South Florida. For more information, please contact digitalcommons@usf.edu. 


\title{
Comment on "Timing of Mantle Upwelling: Evidence for a Passive Origin for the Red Sea Rift" by A. V. McGuire and R. G. Bohannon
}

\author{
T. H. Dixon
}

Earth and Space Sciences Division, Jet Propulsion Laboratory, Pasadena, California

\begin{abstract}
McGuire and Bohannon [1989] argue that the Red Sea must be a passive rift, with crustal extension preceding mantle upwelling, because crustal geotherms calculated from surface heat flow measurements, indicating low thermal gradients, do not agree with geotherms inferred from geothermometry and geobarometry on ultramafic xenoliths, suggesting higher thermal gradients. This disagreement is taken to indicate a lack of thermal equilibrium in the Red Sea region, so that the implied upper mantle hot zone has not had time to heat the upper crust. McGuire and Bohannon [1989] therefore argue that mantle upwelling must be a relatively late phenomenon, consistent with a passive rift scenario. This argument depends critically on two assumptions. First, the surface heat flow data must be representative of the region sampled by the xenoliths. Second, the pressures (P) and temperatures $(\mathrm{T})$ estimated from xenolith compositions must indicate actual PT points in the upper mantle, unbiased by disequilibrium or other error sources in the xenolithbased estimates. Both assumptions are open to question.
\end{abstract}

Morgan [1982] pointed out that heat flow in continental rifts is strongly related to local igneous activity. Available heat flow data for Saudi Arabia [Gettings et al., 1986] are from a Precambrian shield area that has experienced no Tertiary or younger volcanism. Measurements taken $100 \mathrm{~km}$ or more away from the Red Sea coast and thus unaffected by Late Tertiary rifting show low $\left(40-50 \mathrm{~mW} / \mathrm{m}^{2}\right)$ heat flow values typical of stable Precambrian shields. A geotherm calculated on the basis of these measurements using the approach of Lachenbruch and Sass [1977] yields temperatures at the base of the crust $(\sim 40 \mathrm{~km})$ of about $475^{\circ} \pm 50^{\circ} \mathrm{C}$, with the uncertainty indicating the range of plausible values for thermal conductivity and heat production in the upper crust. However, there are no heat flow measurements from the xenolith sample locality, and this region has experienced extensive Tertiary and younger volcanism. Although volcanism began about 30 m.y. ago (see below) most activity has occurred in the last 10 m.y. [e.g., Camp and Roobol, 1989] and there are numerous Quaternary flows. This is clearly an active volcanic province, and typical heat flow values in the xenolith locality probably exceed $100 \mathrm{~mW} / \mathrm{m}^{2}$. If we assume a surface heat flow of $90 \mathrm{~mW} / \mathrm{m}^{2}$ for this region, the same extrapolation to $40 \mathrm{~km}$ yields temperatures at the base of the crust of $1000^{\circ} \pm 100^{\circ} \mathrm{C}$, not significantly different from the temperatures reported by McGuire and Bohannon [1989] for the xenoliths. Thus the argument for thermal disequilibrium between the upper crust and upper mantle appears to be weak. Note that the distance between the xenolith sample locality and the nearest heat flow mea-

Copyright 1990 by the American Geophysical Union.

Paper number 89JB01460.

0148-0227/90/89JB-01460\$02.00 surement exceeds $200 \mathrm{~km}$, a sufficient distance that thermal equilibrium in the last $10 \mathrm{~m}$.y. (the period of most active volcanism) is not likely to be obtained. Advection of heat associated with magma transport is essentially vertical, and so only conductive processes apply in the horizontal direction. Conduction is sufficiently slow that the implied lateral thermal gradients can easily be maintained over the $\sim 10$ m.y. time span.

Second, the geothermometry and geobarometry data need to be interpreted with considerable caution. For example, it is important to demonstrate that the xenoliths in question record equilibrium assemblages that can be uniquely related to an actual PT path in the lithosphere. Zoning is observed in both olivine and spinel in these samples [McGuire, 1988]. Kuo and Essene [1986] report zoning in the Al contents of orthopyroxene and clinopyroxene in similar samples from the same locality. These observations suggest that equilibrium was not obtained for this suite of xenoliths. The $P$ and $T$ estimates are therefore difficult to interpret relative to the surface heat flow measurements, and it seems premature at best to assert that they support a passive rift mechanism.

It is instructive to consider results of xenolith-based $\mathrm{P}$ and $T$ estimates from other localities. These estimates often lie to the high temperature side of a "standard" shield geotherm, possibly reflecting a blocking temperature effect. Unless there has been recrystallization and consequent lowtemperature equilibration, almost all temperature estimates for ultramafic xenoliths based on the two-pyroxene equilibration method appear to have a lower limit of about $750^{\circ}-800^{\circ} \mathrm{C}$ (see, for example, the southern Africa data in Adams and Bishop [1988] and the compilation of Harley [1984]). The petrography of the Saudi Arabian xenoliths does not suggest recrystallization [McGuire, 1988]. If pyroxene geothermometry on nonrecrystallized xenoliths is in fact restricted by blocking temperature effects to a lower limit of about $750^{\circ}-800^{\circ} \mathrm{C}$, then the lack of agreement between geotherms estimated from the two methods is not surprising. Given these uncertainties, differences between temperature estimates at the base of the crust from surface heat flow measurements and from xenolith geothermometry and geobarometry should not be considered indicative of a passive rift mechanism.

Although not the primary focus of their paper, McGuire and Bohannon [1989] assert that available constraints on the timing of uplift also require a passive rift model. However, precise dating of uplift initiation is notoriously difficult. Space does not permit a detailed discussion of this issue (see Dixon et al [1989] for a more complete treatment), but it is useful to consider briefly the primary data used to support the uplift argument of McGuire and Bohannon [1989], namely, the apatite fission track ages presented by Bohannon et al. [1989]. These data show a large degree of scatter, 
with ages ranging from Late Tertiary to Early Cambrian. A few samples lie in the range 14-20 $\mathrm{Ma}$, and these are interpreted to indicate uplift beginning after 14 Ma. However, almost all of these younger samples were taken from the region where Tertiary and younger volcanism is ubiquitous. Since the annealing temperature for apatites is very low $\left(100^{\circ}-150^{\circ} \mathrm{C}\right)$, the apatite fission track ages more likely record local volcanic activity than an accurate uplift history. Kohn and Eyal [1981], Morgan et al. [1985], and Omar et al. [1987] discuss fission track data from regions adjacent to the Red Sea that have not experienced such volcanism. These latter data suggest that uplift began sometime in the period 26-40 $\mathrm{Ma}$, that is, indistinguishable from the beginning of extension (see below).

An important constraint on the timing of mantle activity relative to rifting not discussed by $M c$ Guire and Bohannon [1989], and one that is less ambiguous to interpret, is the timing of volcanism. Although mafic volcanism extends to Recent time, the initiation of mantle upwelling in the region probably predates or at least coincides with the age of the earliest Cenozoic mafic volcanic unit. Bohannon [1986] suggests that Red Sea extension initiated in the period 23-29 $\mathrm{Ma}$. The age of the earliest Tertiary mafic volcanism is $30-32$ Ma (Brown et al., [1984] and E. A. DuBray and D. B. Stoeser (1986), quoted by Bohannon et al. [1989, p. 1687]) and may even extend to $43 \mathrm{Ma}$ [Pallister, 1987]. This suggests that mantle upwelling preceded extension by at least a few million years. Whether this indicates a passive or active rift mechanism is still open to question and perhaps irrelevant; as Crough [1983], Morgan and Baker [1983], and others have pointed out, it is likely that more than one mechanism is required for development of major rifts.

\section{REFERENCES}

Adams, G. E., and F. C. Bishop, The olivine-clinopyroxene geobarometer: experimental results in the $\mathrm{CaO}-\mathrm{FeO}-\mathrm{MgO}-\mathrm{SiO}_{2}$ system, Contrib. Mineral. Petrol., 94, 230-237, 1986.

Bohannon, R. G., Tectonic configuration of the western Arabian continental margin, southern Red Sea, Tectonics, 5, 477-499, 1986.

Bohannon, R. G., C. W. Naeser, D. L. Schmidt, and R. A. Zimmerman, The timing of uplift, volcanism, and rifting peripheral to the Red Sea: A case for passive rifting, J. Geophys. Res., 94, 1683-1701, 1989.

Brown, G. F., D. L. Schmidt, and A. C. Huffman, Geology of the Arabian Peninsula shield area of western Saudi Arabia, U.S. Geol. Surv. Open File Rep., 84-0203, 217 pp., 1984.
Camp, V. E., and M. J. Roobol, The Arabian continental alkali basalt province, part 1, Evolution of Harrat Rahat, Kingdom of Saudi Arabia, Geol. Soc. Am. Bull., 101, 71-95, 1989.

Crough, S. T., Rifts and swells: Geophysical constraints on causality, Tectonophysics, 94, 23-37, 1983.

Dixon, T. H., E. R. Ivins, and B. J. Franklin, Topographic and volcanic asymmetry around the Red Sea: Constraints on rift models, Tectonics, 8, 1193-1216, 1989.

Gettings, M. D., H. R. Blank, W. D. Mooney, and J. H. Healey, Crustal structure of southwestern Saudi Arabia, J. Geophys. Res., 91, 6491-6512, 1986.

Harley, S. L., Comparisons of garnet-orthopyroxene geobarometer with recent experimental studies, and applications to natural assemblages, $J$. Petrol., 25, 697-712, 1984.

Kohn, B. P., and M. Eyal, History of uplift of the crystalline basement of Sinai and its relation to opening of the Red Sea as revealed by fission track dating of apatites, Earth Planet. Sci. Lett., 52, 129-141, 1981.

Kuo, L. C., and E. J. Essene, Petrology of spinel harzburgite xenoliths from the Kishb Plateau, Saudi Arabia, Contrib. Mineral. Petrol., 93, 335-346, 1986.

Lachenbruch, A. H., and J. H. Sass, Heat flow in the United States and the thermal regime of the crust, in The Earth's Crust, Geophys. Monogr. Ser., vol. 20, edited by T. G. Heacock, pp. 626-675, AGU, Washington, D. C., 1977.

McGuire, A. V., Petrology of mantle xenoliths from Harrat al Kishb: The mantle beneath western Saudi Arabia, J. Petrol., 29, 73-92, 1988.

McGuire, A. V., and R. G. Bohannon, Timing of mantle upwelling: Evidence for a passive origin for the Red Sea rift, J. Geophys. Res., 94, 1677-1682, 1989.

Morgan, P., Heat flow in rift zones, in: Continental and Oceanic Rifts, Geodyn. Ser., vol. 8, edited by G. Palmason, pp. 107-122, AGU, Washington, D. C., 1982.

Morgan, P., and B. H. Baker, Introduction: Processes of continental rifting, Tectonophysics, 94, 1-10, 1983.

Morgan, P., F. K. Boulos, S. F. Hennin, A. A. El Sherif, A. A. El Sayed, N. Z. Basta, and Y. S. Melek, Heat flow in eastern Egypt: The thermal signature of a continental breakup, J. Geodyn., 4, $107-131,1985$.

Omar, G. I., B. P. Kohn, T. M. Lutz, and H. Faul, The cooling history of Silurian to Cretaceous alkaline ring complexes, South Eastern Desert, Egypt, as revealed by fission-track analysis, Earth Planet. Sci. Lett., 83, 94-108, 1987.

Pallister, J. S., Magmatic history of Red Sea rifting: perspective from the central Saudi Arabian coastal plain, Geol. Soc. Am. Bull., 98, 400-417, 1987 .

T. H. Dixon, Jet Propulsion Laboratory, 4800 Oak Grove Drive, Pasadena, CA 91109.

(Received March 21, 1989; revised June 30, 1989; accepted July 10, 1989.) 